International Journal of Life Sciences
Available online at www.sciencescholar.us
Vol. 4 No. 2, August 2020, pages: $52-58$
e-ISSN: 2550-6986, p-ISSN: 2550-6994
https://doi.org/10.29332/ijls.v4n2.439

\title{
Legalization of Land Pawning at Balinese Community Customs in North Lombok
}

(CrossMark

\author{
I Gusti Ayu Aditi a
}

Manuscript submitted: 09 May 2020, Manuscript revised: 18 June 2020, Accepted for publication: 27 July 2020

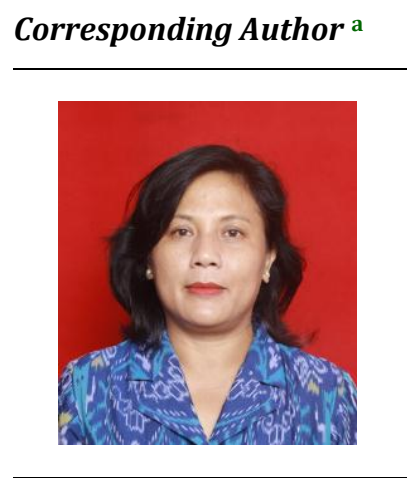

Keywords

agricultural land;

Balinese community

customs;

customary law;

land pawning;

legalization;

\begin{abstract}
This study aims to conduct a study of land pawning legalization, particularly regarding the basis and principles of pawning agricultural land in Balinese community customs in North Lombok. This phenomenon is related to the still implementation of the land pawning system under customary law, in the sense that the implementation still refers to the interests of people who have strong capital. This research is designed in a qualitative descriptive research type using a case study approach. The results of this study found that the Legal Basis and the principle of implementing agricultural land pawning refer to the national law which is imbued with customary law, namely with the characteristics of communalistic customary law, religious magic in dealing in agreement in words and actions. There are two kinds of land pawning, namely dead pawning, and life pawning. Dead pawning recognizes the time limit for land returning without a living pawning ransom. Living pawning does not recognize the minimum time limit that the mortgaged can do one harvest before it can be redeemed. Transactions carried out with legal assistance or testimony from the hamlet head or village head will be clear, guaranteed, or protected by law, especially against claims from third parties.
\end{abstract}

International Journal of Life Sciences (C) 2020. This is an open access article under the CC BY-NC-ND license (https://creativecommons.org/licenses/by-nc-nd/4.0/).

\section{Contents}

Abstract 52

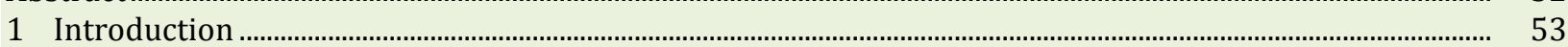

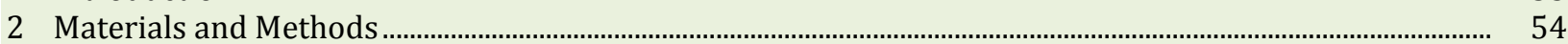

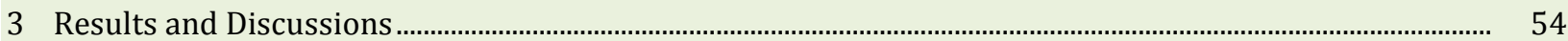

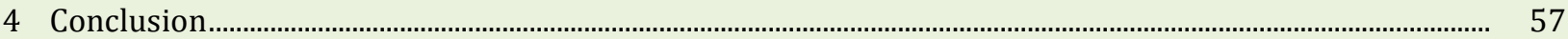

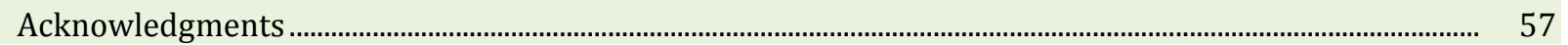

a Sekolah Tinggi Agama Hindu Negeri Gde Pudja Mataram, Mataram, West Nusa Tenggara 
References

\section{Introduction}

The relationship between humans and land cannot be separated because human survival is very dependent on the existence of land and vice versa, the land also requires human protection for its existence as land that has meaning and function. The land has a high selling value compared to other objects, so the land has a very important meaning in human life, as a place to grow crops for farmers, where all living things live, even those who die need land as a burial place (Rony, 1998; Windia \& Sudantra, 2006; Wirawan, 2018; Yamin, 2004). Also, the land is a place for the production of goods and services so that the land has economic and legal value, if the land which is already controlled by each individual is disturbed by other parties, it must obtain legal protection. In connection with the multi-function of land in human life, the land has more value than other objects economically (Arikunto, 2006; Mukti Fajar \& Achmad, 2010; Hasan, 1988; Alting, 2010).

The condition of economic growth in the community is so fast, it requires fast and easy transactions to get money, on the other hand, and the condition of indigenous peoples is very rigid in defending their land. It is impossible to sell off the land because it is tied to land ownership status. The people of Bali in Lombok who think that land has magical religious value because it is associated with magical things and is believed to be a place for ancestral spirits who have died, and an inheritance system that is very difficult to transfer of land is bound by legal ties such a complicated family (Muhammad, 1995; Mochtar Naim, 1968; Raharjo, 2000). Therefore, pawning land or mekantah in Balinese community customs in Lombok is the right and fast solution in society. Land pawning is an agreement originating from customary law which often creates debate and dispute due to the tug of war between the National Agrarian Law and Customary Law.

Land pawning in Sasak society is known as mesandak, which is an agreement that causes the land to be handed over by receiving cash for an amount of money which the owner has the right to take the land back by paying the same amount of money. Land pawning is a norm that arises from the realization of social life, which has legal value and yet is in the life of the people who use it. The rise of land pawning transactions in the Balinese Hindu community in North Lombok often creates conflicts because there is no harmony between the prevailing regulations and local customary law, while the law states that land pawning has exceeded the 7 years, automatically the land returns to the owner is without ransom, while the prevailing customary law does not recognize this.

Land pawning in customary law is a relationship between a person and land owned by another person who has received the pledge and as long as the money has not been returned, the pledge is still ongoing and the land concerned is still under the control of the pawner until the ransom is returned as much as the initial money given by the landowner. Based on the preliminary survey, land pawning transactions in community customs that occurred in North Lombok were not registered or made explicit in the case that it is clearly regulated in government regulation Number 24 of 1997 that pawning for agricultural land must be proven by a deed made by the Land Titles Registrar

The phenomenon that is developing in society today is that there is still a system of land pawning under customary law, in the sense that the implementation still refers to the interests of people who have strong capital (Calderón, 2004; Ali et al., 2014; Ding, 2003). So that it is necessary to legalize the regulation on the basis and principle of pawning agricultural land in the Balinese community customs in North Lombok and how the formulation of regulation on should land pawning that can fulfill a sense of justice.

\section{Theory Basis of Research}

Living Law Theory According to Ehrlich, society is a general idea that can be used to signify all social relationships, namely family. Living law theory is a law that lives in society. According to Eugen Ehrlich (1967), the center of activity of the development of law lies not in the law, not in the science of law, nor in court decisions, but in society itself (Achmad Ali, 2009).

In formulating regulations regarding land pawning that can fulfill a sense of justice, it is necessary to look Aditi, I. G. A. (2020). Legalization of land pawning at Balinese community customs in North Lombok. International Journal of Life Sciences, 4(2), 52-58. https://doi.org/10.29332/ijls.v4n2.439 
at the laws that live during society. In Indonesia, until now, it has recognized statute law, this can be seen from the prevailing regulations in the State of Indonesia, namely based on statutory regulations.

According to John Austin in his book (Khuzaifah, 2019) states that the only source of law is the highest power in the State. The existence of Living law in Indonesia is recognized by the existence of Article 18b of the State Constitution. The Republic of Indonesia of 1945, which states that the State recognizes and respects units of regional government that are special or special as regulated in law. Even though Indonesia adheres to a statute law system, the existence of living law or laws that grow in society is still respected. From the understanding of the theory of living law, it can be found directly in real life in customary law communities by looking at the growing and developing norms, habits, and social facts that are adhered to by the local community as a regulatory framework of rules governing human behavior (Luers et al., 2006; Wallace \& Williamson, 2006; Chen \& Wu, 2020).

\section{Materials and Methods}

This type of research is empirical juridical research, which is a study that not only emphasizes the written law but sees the applicable law in society. This type of empirical normative research with a statutory and conceptual approach. The data sources are primary data and secondary data with inductive thinking logic. Primary data obtained in the field after being linked with legal provisions relating to land pawning, both based on Balinese Lombok customary law and National Agrarian Law will obtain living legal principles in the implementation of land pawning.

\section{Results and Discussions}

\subsection{Basic and Principles of Agricultural Land Pawning in Balinese Community Customs in North Lombok}

Living Law Theory is a law that lives in society. According to Eugen Ehrlich (1967), the center of activity of the development of law lies not in the law, not in the science of law, nor court decisions, but in society itself (Achmad Ali, 2009).

In formulating regulations regarding land pawning that can fulfill a sense of justice, it is necessary to look at the laws that live during society. In Indonesia, until now, it has recognized statute law, this can be seen from the prevailing regulations in the State of Indonesia, namely based on statutory regulations. The discussion regarding the provisions of the laws and regulations regarding land pawning has a sense of justice or not to the Balinese community customs in North Lombok because justice here is a legal goal to be achieved, to obtain equality in society, as well as for legal certainty. Rights regarding land before the enactment of the National Law derive from Customary Land Law (Harsono, 2008).

Likewise, for right agricultural land pawning, basically pawning of agricultural land is related to Customary Law, because the practice of pawning itself has existed and developed in customary communities which are then reduced in statutory regulations. Along with the development of law in Indonesia, the land law was created. Western land law regulations, with a few exceptions, no longer apply rights to land whether derived from Western law. The following are the provisions of the national law governing the pawning of agricultural land.

1) Law. No. 5 of 1960 concerning Peraturan Dasar Pokok-Pokok Agraria (Basic Agrarian Principles, hereinafter abbreviated to UUPA). Article 53 which is connected with the previous article, namely Article 52 Paragraph (2) which explains that rights that are temporary including liens will be eliminated.

2) UU (Law) no. 7 of 1970 regarding the abolition of "Landreform". In this law, it is explained that all land pawning cases are examined and decided by the court within the domain of the general court

3) UU (Law) no. 56 Prp of 1960 Article 7 Paragraph (1) and Paragraph (2) which regulates the deadline for pawning agricultural land and the method of redemption as well as Article 10 which regulates sanctions for violations of Article 7 Paragraph (1) and (2). 
4) Regulation of the Minister of Agriculture and Agrarian Affairs 20 of 1963 concerning guidelines for solving pawning problems.

5) PP (Government regulations) No. 24 of 1997 which regulates the proof of pawning of agricultural land with deeds made by PPAT.

6) Decree of the Supreme Court of the Republic of Indonesia dated 11 May 1955 No. 26 / K / Sip / 1955 concerning the change in the value of the rupiah when the pawning began to occur on agricultural land and the time of redemption.

7) Decree of the Minister of Agriculture and Agrarian Affairs No. SK / 10 / Ka1960 concerning the affirmation of the enactment of Article 7 of Law No.56 Prp of 1960 also applies to Perennial Pawning.

Thus, the legal basis for pawning agricultural land is in the form of Undang-Undang (Laws), Government Regulations, and Regulations of Agrarian Ministry, all of which are summarized in the National Law. According to Article 7 of the Government Regulation in lieu of Law (Pеrpu) Number. 56 of 1960 concerning the Determination of the Area of Agricultural Land which reads:

"Whoever controls agricultural land with a lien since this regulation comes into force for 7 (seven) years or more is obliged to return the land."

The Balinese community in Tanjung Subdistrict prefer to pawn their agricultural land instead of selling. According to the villagers, they preferred this tradition because the landowner did not lose ownership of the agricultural land which has been pawned. They are also not bothered or bothered with the matter of measuring agricultural land choosing a mortgagee. They prefer to pawn their agricultural land according to traditions with customary laws than other methods.

In this case, actually what is pawning is not the right to own the land, but the right to control over the land, where the recipient of the pledge as long as the land is under control he can use and enjoy the results of the pawning land. As long as the pawning land has not been redeemed by the landowner or the pledge recipient, the land is controlled by the landowner. The emergence of this lien is due to a person's need for money that cannot be postponed so that if he cannot get a loan, this transaction is carried out.

\subsection{Practices of Land Pawning in Balinese Communities Customs in North Lombok}

Basically, this lien arises due to a person's need for money that cannot be postponed, so that if someone cannot obtain a loan, this transaction is carried out. The pawning institution is an institution that has been living in Indonesian society for a long time, in the customary law, this pawning transaction is sometimes carried out with the help of the head of the association or the village apparatus so that it is protected by customary law and so that legal action is considered clear. For legal protection, his assistance to the head of the association or village guard is given witness money.

The Balinese ethnic community who live in the Tanjung sub-district where they mingle with the Sasak people call pawning as the term "mekantah", which is a pawning transaction for agricultural land in the form of rice fields as collateral for debt and the land is used by the pawn recipient. People who make a pawn are called "nanggap" who gives the pawn.

In general, the pawning agreement for agricultural land in North Lombok Regency is more of a social nature to help fellow citizens experiencing economic difficulties. Departing from the feeling of helping, the pawn recipient lends the money to the pawnbroker, as gratitude for lending money, they give land or rice fields to the pawn recipient as collateral for debt and to be cultivated or cultivated.

In the case of land pawning in the Tanjung community, there are 2 (two) forms, namely dead pawning and living pawning. Meanwhile, what is meant by death pawning is using an agreed period, namely, several times planting or harvesting after that, the land which is used as a guarantee will return to the owner without ransom.

For a living pawn is a pawn where the pawn recipient must return the ransom according to the amount borrowed but there is no time limit for the return of the pawn or the ransom even until the owner of the pawn

Aditi, I. G. A. (2020). Legalization of land pawning at Balinese community customs in North Lombok. International Journal of Life Sciences, 4(2), 52-58. https://doi.org/10.29332/ijls.v4n2.439 
has children and grandchildren the money has just been returned, the land used as collateral must be returned.

According to Customary Law, land planners cannot sue the landowner to redeem the pawning land. Therefore, if the mortgagee needs money, he can take two ways, namely by "transferring of pawning" doorverpanding or by "doubling of pawning" onderverpanding.

The meaning of "transferring of pawning" is pawning of the pawning land again to another person with the approval of the landowner so that the legal relationship between the landowner or pawn provider and the first pawn recipient is transferred to the second pawn recipient.

Meanwhile, what is meant by "doubling of pawning" is that the first mortgagee pawn the pawning land again to the second mortgagee recipient without the consent of the pawning giver. So, the legal relationship applies between the pawning giver and the first mortgagee and between the first mortgagee and the second mortgagee. If the landowner will redeem the land, then the second mortgagee must return the pawning land to the first mortgagee and the first mortgagee will return the pawning land to the land owner.

If the pledge giver pawns his land to the pawning recipient because he has a debt to the pawning recipient, and the mortgagee recipient then works on the land by calculating the debt of the mortgagee until it is paid off from the results of the pawning land, after calculating the debt is paid off, then this form of land pawning is called "mortgage debt settlement" or "debt settlement agreement" delgingsovereenkomst. In the implementation of pawning agricultural land, the object is not labor or plants, but land. Since the object is the land, it must be done with the knowledge of the association head or the village head. This is to get stronger legal certainty.

In Peraturan Pemerintah (Government Regulation) No. 24/1997 that the pawning of agricultural land must be proven by a deed made by Pejabat Pembuat Akta Tanah (the Official for Making Land Deeds). Apart from the issue of registration of pawning for agricultural land, there were indications of irregularities in one of the pawning redemptions for agricultural land, for example, the pawn redemption agreement was not following the rules for the amount of pawn redemption as stipulated in Article 7 of UU (Law) No. 56 Prp. 1960.

There is a pawning practice with a specified period is five years. The amount of land pawn redemption money that must be paid by the pawnshop seller is an amount of money obtained from pawning the farmland. Seeing the implementation of pawning for agricultural land in Tanjung Village, pawn sellers tend to suffer losses. This is because the pawn seller should only pay the pawning redemption in the amount of money that has been calculated following the provisions of the formula in Article 7, but the pawn seller redeems his land with an amount of money obtained when he sells the pawning on the farm, while the pawn buyer has already benefited from the results the earth on the farm pawn.

Responding to such conditions, the village head demands a role in directing the community in implementing the pawning of agricultural land to comply with applicable regulations. This is because the village head is obliged to improve the welfare of the community as regulated in Government Regulation no. 72 of 2005 which regulates the Village. The responsibility of the village head in improving the welfare of his community concerning pawning agricultural land should be able to make pawning of agricultural land as a way to create welfare in the community.

This can be done by striving for citizens to carry out pawning following the applicable National Law. By heeding the regulations in the practice of pawning agricultural land, it can prevent the pawn from being extorted so that community welfare can be achieved.

\subsection{Arrangements of Land Pawning to Fulfill the Justice}

In human life, the land cannot be separated from all the actions of the human being itself because the land is a place for humans to live and continue their life. Therefore, the land is needed by every member of the community, so that there are often disputes between people, especially those concerning land. For this reason, we need principles that regulate the relationship between humans and land.

The whole legal system that develops and develops in the intercourse of life among humans is very closely related to the use as well as to avoid disputes and the best possible use of land. This is what is regulated in the customary land law. From the provisions of this land law, rights, and obligations that are closely related to existing rights over land will emerge. 
In the implementation of Land Transactions in Customary Law related to the general nature of Indonesian Customary Law, it becomes the basis for a characteristic of the position of land in customary communities and land transactions in Customary Law. In the nature of "religio magis", it is stated that the land is the residence of the fellowship protectors and the spirits of the ancestors of the community.

The land is the living dependence of a community that is still living in isolation, such a society which is more concerned with public interests than private interests, while for cash it contains real actions, a symbolic act or pronouncement of the legal act in question has been completed at that time, simultaneously at the same time when the act or utterance required by customary law.

The sale and purchase of land to indigenous peoples are also in cash because payment and transfer of land occur simultaneously. The concrete nature of land transactions can be seen in the existence of a "panjer" as a visual symbol of the sale and purchase transaction or transfer of land rights that will be carried out. So, four elements of the characteristics of Indonesian Customary Law can also be found in the position of land in customary communities and land transactions in Customary Law

The land transaction to obtain legal protection should be made in writing and the transaction witnessed by the lowest hamlet head. With transactions carried out in front of the hamlet head or village head, it can make the transaction clear or not dark. For this assistance, the hamlet head or village head usually received witness money. Transactions carried out with legal assistance or testimony from the hamlet head or village head will be clear, guaranteed, or protected by law, especially against a lawsuit from a third party. Inland transactions, testimony from the village head, or hamlet head has an important position to obtain legal protection against claims from third parties. Although in fact, the testimony from the hamlet or village head is not a valid condition of the agreement.

\section{Conclusion}

The results of this study obtained three conclusions as research findings. First, the Legal Basis and Principles for Implementing Agricultural Land Pawn, which refers to the National Law which is animated by Customary Law, namely by the characteristics of Communalistic Customary Law, religious magic cash in transactions as one in words and actions. Second, the practice of Land Pawn Implementation in Balinese Indigenous Communities in North Lombok. There are two kinds of land pawning in this community, namely dead pawning, and living pawning. Dead pawning recognizes the time limit for land returning without a living pawning ransom. Third, the arrangement on Land Pawn That Can Fulfill a Sense of Justice. Transactions carried out with legal assistance or testimony from the hamlet head or village head will be clear, guaranteed, or protected by law, especially against a lawsuit from a third party. Inland transactions, testimony from the village head, or hamlet head has an important position to obtain legal protection against claims from third parties. Although in fact, the testimony from the hamlet or village head is not a valid condition of the agreement. The recommendation of research results in the implementation of land pawning must involve elements of the village apparatus as witnesses to avoid undesirable things such as conflicts.

\section{Acknowledgments}

I am grateful to two anonymous reviewers for their valuable comments on the earlier version of this paper.

Aditi, I. G. A. (2020). Legalization of land pawning at Balinese community customs in North Lombok. International Journal of Life Sciences, 4(2), 52-58. https://doi.org/10.29332/ijls.v4n2.439 


\section{References}

Achmad, A. (2009). Menguak Teori Hukum dan Teori Peradilan. Jakarta: Kencana.

Ali, D. A., Deininger, K., \& Goldstein, M. (2014). Environmental and gender impacts of land tenure regularization in Africa: Pilot evidence from Rwanda. Journal of Development Economics, 110, 262-275. https://doi.org/10.1016/j.jdeveco.2013.12.009

Alting, H. (2010). Dinamika Hukum dalam Pengakuan dan Perlindungan Hak Masyarakat Hukum Adat Atas Tanah (masalalau, Masa Kini dan Masa Mendatang).

Arikunto, S. (2006). Prosedur penelitian suatu pendekatan. Jakarta: Rineka Cipta.

Calderón, J. (2004). The formalisation of property in Peru 2001-2002: the case of Lima. Habitat International, 28(2), 289-300. https://doi.org/10.1016/S0197-3975(03)00072-9

Chen, J., \& Wu, F. (2020). Housing and land financialization under the state ownership of land in China. Land Use Policy, 104844. https://doi.org/10.1016/j.landusepol.2020.104844

Ding, C. (2003). Land policy reform in China: assessment and prospects. Land use policy, 20(2), 109-120. https://doi.org/10.1016/S0264-8377(02)00073-X

Ehrlich, E., \& Rehbinder, M. (1967). Recht und Leben: gesammelte Schriften zur Rechtstatsachenforschung und zur Freirechtslehre. Schriftenreihe.

Harsono, B. (2008). Hukum Agraria Indonesia: Sejarah Pembentukan Undang-Undang Pokok Agraria, Isi dan Pelaksanaanya, Edisi Revisi, Cet. 12. Jakarta (ID): Djambatan.

Hasan, F. (Ed.). (1988). Dinamika Masyarakat dan Adat Minangkabau. Departemen Pendidikan dan Kebudayaan, Pusat Penelitian Universitas Andalas.

Khuzaifah, E. (2019). Studi Tentang Dinding Penahan (Retaining Wall). Swara Patra, 9(1), 7-18.

Luers, A. L., Naylor, R. L., \& Matson, P. A. (2006). A case study of land reform and coastal land transformation in Southern Sonora, Mexico. Land Use Policy, 23(4), 436-447. https://doi.org/10.1016/j.landusepol.2005.04.002

Mochtar Naim (Ed.). (1968). Menggali hukum tanah dan hukum waris Minangkabau. Center for Minangkabau Studies Press.

Muhammad, B. (1995). Pokok-pokok hukum adat. Pradnya Paramita.

Mukti Fajar, N. D., \& Achmad, Y. (2010). Dualisme Penelitian Hukum: Normatif \& Empiris. Pustaka Pelajar.

Raharjo, S. (2000). Ilmu Hukum, Bandung. PT Citra Aditya Bakti.

Rony, H. S. (1998). Metode Penelitian Hukum dan Jurimetri.

Wallace, J., \& Williamson, I. (2006). Building land markets. Land use policy,23(2), 123-135. https://doi.org/10.1016/j.landusepol.2004.07.003

Windia, W. P., \& Sudantra, K. (2006). Pengantar hukum adat bali. Lembaga Dokumentasi Dan Publikasi Fakultas Hukum Universitas Udayana, Denpasar.

Wirawan, I. W. A. (2018). Maintaining social relationship of Balinese and Sasak ethnic community. International journal of social sciences and humanities, 2(1), 92-104.

Yamin, M. (2004). Gadai Tanah Sebagai Lembaga Pembiayaan Rakyat Kecil.

\section{Biography of Author}

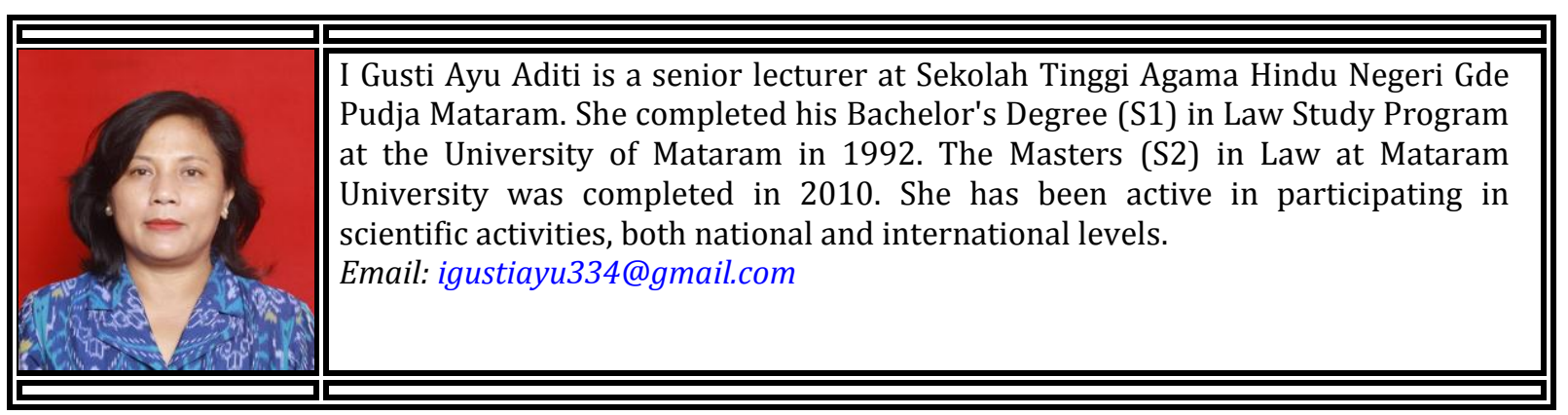

